\title{
PENGARUH PERUBAHAN BI RATE TERHADAP MARKET RETURN DAN VOLATILITAS INDEKS LQ45
}

\author{
Alan Fatih \\ Email: alan-f-11@feb.unair.ac.id \\ Fitri Ismiyanti \\ Email: fitri.ismiyanti@feb.unair.ac.id \\ Departemen Manajemen Fakultas Ekonomi dan Bisnis Universitas Airlangga
}

\begin{abstract}
This study aimed to examine the effect of the announcement of the change in the $\mathrm{BI}$ rate to market return and volatility on the index LQ45 during the period March 2010 to February 2015 by using inflation and industrial production index as variable control. This study uses multiple regression analysis $(a=5 \%)$. Regression results show that changes in the $\mathrm{Bl}$ rate has no significant effect on the market return. These results indicate that at the time of the announcement of the BI rate does not give any influence on the market return LQ45. The different results shown by the effect of changes in the BI rate to return volatility LQ45. Volatility increased with the announcement of the increase in the Bl rate changes. Furthermore, the control variables, inflation and the industrial production index has no significant effect either on the market returns and volatility of LQ45 so that this control variable can not be used to predict market returns and volatility of LQ45 current BI rate announcement.
\end{abstract}

Keywords: BI rate, volatility, LQ45 Index, Inflation, Industrial Production Index

\section{Pendahuluan}

Pasar keuangan memegang peranan yang penting dalam perekonomian karena pasar keuangan merupakan tempat menyalurkan dana dari pihak yang kelebihan dana kepada pihak yang kekurangan dana. Salah satu bentuk dari pasar keuangan adalah pasar modal yaitu pasar dimana instrumen ekuitas dan utang jangka panjang diperdagangkan. Pasar modal diharapkan mampu meningkatkan aktivitas perekonomian karena pasar modal merupakan alternatif pendanaan jangka panjang bagi perusahaan.

Investasi pada dasarnya merupakan kegiatan pengalokasian dana pada aset produktif dengan harapan mendapatkan keuntungan di masa depan. Keuntungan investor dalam 


\section{Alan Fatih \\ Fitri Ismiyanti}

investasi saham berupa dividen dan kenaikan harga saham. Naik turunnya harga saham yang di tentukan oleh pasar menyebabkan munculnya harga baru dari suatu saham yang berdampak pada selisih harga saham awal dengan harga saham baru. Perubahan harga saham ini tidak bisa diprediksi dengan pasti karena mengikuti penawaran dan permintaan pasar yang tentunya bereaksi terhadap informasi, sehingga semakin banyak investor mengetahui tentang informasi yang ada maka prediksi atas harga saham pun akan semakin akurat. Fluktuasi harga saham di pasar modal mencerminkan tingkat risiko tertentu yang dihadapi oleh investor, hal ini dapat digambarkan oleh volatilitas pasar modal. Volatilitas pasar saham di negara berkembang umumnya jauh lebih tinggi daripada di negara maju (Bekaert dan Harvey, 1995). Tingginya volatilitas di negara berkembang pada umumnya dilatarbelakangi oleh ketidakstabilan ekonomi.

Sebagai otoritas moneter, Bank Indonensia menggunakan instrumen Bl rate sebagai implementasi kebijakan moneter untuk menekan laju inflasi dengan mempengaruhi aktivitas perekonomian. Pada 18 November 2014, Bank Indonesia menetapkan kenaikan BI rate sebesar 25 bps menjadi 7.75\% berdasarkan Rapat Dewan Gubernur, kenaikan ini dipicu oleh kenaikan BBM bersubsidi. Kenaikan BI rate ini diharapkan dapat mengontrol dan menekan inflasi pasca kenaikan BBM bersubsidi dimana inflasi pada November 2014 sebesar $6.23 \%$ dengan target pemerintah 4+-1\%. Sebelumnya pada 12 September dan 12 November 2013, Bank Indonesia juga menetapkan kenaikan BI rate sebesar 25 bps menjadi 7,25\% dan 7,50\%. Sedangkan pada 11 Juli dan 29 Agustus 2013 terjadi kenaikan BI rate masing-masing sebesar 50 bps menjadi 6,50\% dan $7,00 \%$, kenaikan ini dipicu oleh kondisi perekonomian global yang melambat dan diliputi ketidakpastian yang tinggi serta pertumbuhan perekonomian nasional yang juga melambat. Di sisi lain, indeks LQ45 juga mulai melemah pada Juni 2013. Pelemahan ini semakin diperparah pada bulan Juli dan Agustus bersamaan dengan naiknya Bl rate sebesar 50 bps pada bulan Juli dan Agustus. Hal tersebut mengindikasikan pasar saham mulai merespon kebijakan moneter yang dikeluarkan Bank Indonesia dengan menaikan Bl rate. Chulia et al. (2009) menjelaskan bahwa kenaikan bunga bank sentral merupakan informasi buruk (bad news) bagi pasar saham. Kekhawatiran ini dapat mendorong investor untuk menjual saham-sahamnya yang akan menyebabkan penurunan pada sejumlah harga saham dan mengakibatkan pendapatan negatif.

\section{Landasan Teori dan Pengembangan Hipotesis}

\subsection{Landasan Teori}

\subsubsection{Pasar Modal}




\section{Jurnal Manajemen Teori dan Terapan Tahun 8. No. 1, April 2015}

Pasar modal menurut Latumaerissa (2011:353) adalah pasar yang menyediakan sumber pembelanjaan dengan jangka waktu yang relatif panjang, yang diinvestasikan pada barang modal untuk menciptakan dan memperbanyak alat-alat produksi dan akhirnya meningkatkan kegiatan perekonomian. Undang-undang Nomor 8 tahun 1995 tentang Pasar Modal, pasar modal adalah kegiatan yang berkaitan dengan penawaran umum dan perdagangan efek, perusahaan publik yang berkaitan dengan efek diterbitkannya, serta lembaga dan profesi yang berkaitan dengan efek. Efek yang dimaksud antara lain adalah saham.

Saham adalah tanda penyertaan atau kepemilikan seseorang atau badan dalam suatu perusahaan. Untuk mengukur perilaku saham secara umum dapat menggunakan indeks. Gitman dan Joehnk (2005:97) dan Reilly dan Brown (2012:116) menjelaskan bahwa indeks saham dapat digunakan untuk tolak ukur atas penilaian kinerja dari portofolio individu. Oleh karena itu, jika pasar secara keseluruhan naik, portofolio individu mungkin juga nilainya akan meningkat.

\section{A. Market Return}

Menurut Gitman dan Joehnk (2005:133) return adalah tingkat keuntungan yang didapatkan dari investasi. Tingkat persentase keuntungan dan kerugian dari pengembalian dapat diperoleh dari perbedaan harga antara harga jual dan beli atau disebut Holding Period Yield (HPY). Tingkat pengembalian aset keuangan karena perubahan harga, sering diukur dengan perbedaan harga log-nya yang terdistribusi secara normal (Alexander, 2001:4). Indeks harga saham sering kali digunakan untuk mengukur tingkat pengembalian pasar. Apabila data yang digunakan adalah indeks LQ45, maka R† merupakan tingkat pengembalian pasar dan P† merupakan nilai indeks LQ45 pada periode t.

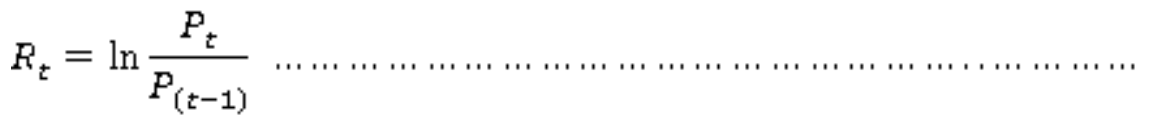

Keterangan :

$$
\begin{array}{ll}
\mathrm{R}_{\dagger} & =\text { tingkat pengembalian pasar pada periode ke- } \dagger \\
\mathrm{In} & =\text { natural logaritma } \\
\mathrm{P}_{\dagger} & =\text { harga pasar pada periode ke } \dagger \\
\mathrm{P}_{(t-1)} & =\text { harga pasar pada periode ke }{ }^{\dagger-1}
\end{array}
$$

\section{B. Volatilitas}




\section{Alan Fatih \\ Fitri Ismiyanti}

Volatilitas adalah kecenderungan harga untuk berubah di luar ekspektasi. Menurut Alexander (2001:4) volatilitas adalah ukuran dispersi dalam kepadatan probabilitas. Volatilitas return mencerminkan ukuran kecepatan pasar dalam merespon perubahan harga. Dalam statistik volatilitas return diukur menggunakan standar deviasi dari return saham, semakin tinggi volatilitas return maka saham akan semakin berisiko. Gospodinov dan Jamali (2012) mengukur volatilitas pasar saham dengan realized volatility di mana volatilitas pasar saham di ukur dengan perbedaan historis harga saham.

$$
R V_{d, t}=\sqrt{\frac{1}{n_{t}} \sum_{d=1}^{n_{t}} R_{t}^{2}}
$$

Keterangan :

$$
\begin{array}{ll}
\mathrm{RV}_{d, t} & =\text { Realized Volatility pada hari } \mathrm{d} \text { bulan }{ }^{\dagger} \\
\mathrm{n}_{t} & =\text { jumlah hari perdagangan dalam bulan }{ }^{\dagger} \\
\mathrm{R}_{+} & =\text {tingkat pengembalian pasar pada periode ke- } \dagger \text { diukur dengan persamaan }
\end{array}
$$

\subsubsection{Efisiensi Pasar Modal}

Pasar modal dikatakan efisien apabila harga saham dengan cepat menyesuaikan datangnya informasi baru sehingga harga saham saat ini mencerminkan semua kemungkinan informasi yang ada. Dengan adanya konsep ini, investor akan dengan cepat menggabungkan semua informasi yang tersedia dalam keputusan mereka tentang harga saham di mana mereka bersedia untuk membeli atau menjual saham sehingga semakin kompetitifnya investor dalam membuat keputusan, harga saham pun akan dengan cepat menyesuaikan seiring datangnya informasi baru. Penyesuaian ini tidak selamanya sempurna, terkadang terlalu besar maupun terlalu kecil. Bagaimanapun juga, harga saham akan menyesuaikan dan kemudian terkoreksi dan membuat harga baru. Fama (1970) membagi hipotesis pasar efisien ke dalam tiga sub-hipotesis berdasarkan sekumpulan informasi yang tersedia di pasar yaitu bentuk lemah, semi kuat dan kuat.

\subsubsection{Kebijakan Moneter Bank Indonesia}

Kebijakan moneter merupakan kebijakan otoritas moneter atau bank sentral dalam bentuk pengendalian besaran moneter untuk mencapai perkembangan kegiatan 
perekonomian yang diinginkan. Dalam melaksanakan tugasnya Bank Indonesia dipimpin oleh Dewan Gubernur. Penentuan kebijakan Bank Indonesia diputuskan dalam Rapat Dewan Gubernur (RDG) sebagai forum tertinggi dalam pengambilan keputusan. RDG sekurangkurangnya diselenggarakan sekali dalam sebulan untuk menetapkan kebijakan umum di bidang moneter serta sekali dalam seminggu untuk mengevaluasi atas pelaksanaan kebijakan moneter atau menetapkan kebijakan lain yang bersifat prinsip dan strategis (Latumaerissa, $2011: 66)$.

Dalam rangka mencapai sasaran akhir kebijakan moneter, Bank Indonesia menerapkan kerangka kebijakan moneter melalui BI rate yang mencerminkan stance kebijakan moneter yang ditetapkan oleh BI. Respon kebijakan moneter dinyatakan dalam perubahan $\mathrm{BI}$ Rate (secara konsisten dan bertahap dalam kelipatan 25 basis poin (bps). Menurut Mishkin (2007) dalam Gospodinov dan Jamali (2012) menjelaskan bahwa saluran yang menghubungkan dampak kebijakan moneter pada pasar saham adalah tingkat diskonto yang digunakan untuk menilai arus kas dari ekuitas, selain itu juga melalui financial leverage. Penelitian Thorbecke dan Alami (1994) menunjukkan bahwa informasi the fed menaikan federal funds rate target menyebabkan adanya penurunan pada harga saham seketika. Bekaert dan Harvey (1995) menyatakan bahwa volatilitas pasar saham di negara berkembang umumnya jauh lebih tinggi daripada di negara maju. Tingginya volatilitas di negara berkembang pada umumnya dilatarbelakangi oleh ketidakstabilan ekonomi. Berdasarkan teori dan penelitian sebelumnya maka hipotesis penelitian adalah sebagai berikut :

\section{H1 : Perubahan BI rate berpengaruh negatif signifikan terhadap market return indeks LQ45.}

\section{H2 : Perubahan BI rate berpengaruh positif signifikan terhadap volatilitas indeks LQ45.}

\section{Metode Penelitian}

\subsection{Metode Seleksi dan Pengumpulan Data}

Pada penelitian ini menggunakan populasi dari data Indeks LQ45, BI rate, inflasi dan indeks produksi industri selama bulan Maret 2010 sampai Februari 2015. Teknik penentuan sampel dalam penelitian ini adalah dengan metode purpose sampling, yaitu suatu metode yang digunakan untuk memilih populasi yang akan dijadikan sampel dengan menggunakan pertimbangan dan batasan tertentu sehingga sampel yang dipilih relevan dengan tujuan penelitian. Berdasarkan obyek penelitian, maka penulis menetapkan kriteria pemilihan sampel yang diteliti sebagai berikut : (a) Periode Maret 2010 hingga Februari 2015, (b) Menggunakan pengumuman Bl rate yang terakhir apabila terdapat lebih dari satu kali pengumuman pada setiap bulannya. 


\subsection{Jenis dan Pengukuran Variabel}

Tabel 3.1

Jenis dan Pengukuran Variabel

\begin{tabular}{|c|c|c|}
\hline $\begin{array}{c}\text { Jenis } \\
\text { Variabel }\end{array}$ & Variabel & Rumus Perhitungan \\
\hline Dependen & $\begin{array}{l}\text { Market Return } \\
\qquad(\mathrm{R})\end{array}$ & $R_{t}=\ln \frac{P_{t}}{P_{(t-1)}}$ \\
\hline Dependen & $\begin{array}{c}\text { Volatilitas } \\
(\Delta \mathrm{RV})\end{array}$ & $\begin{array}{l}\text { Diukur dengan perubahan Realized Volatility pada } \\
\text { persamaan 2.2. } \\
\Delta R V=R V_{t}-R V_{t-1}\end{array}$ \\
\hline Independen & $\begin{array}{l}\text { Perubahan } \mathrm{BI} \\
\text { rate } \\
(\Delta \mathrm{BI})\end{array}$ & $\begin{array}{l}\text { Diukur dengan perubahan BI rate } \\
\triangle B I=B I_{t}-B I_{t-1}\end{array}$ \\
\hline Kontrol & $\begin{array}{l}\text { Inflasi } \\
\text { (INF) }\end{array}$ & $I N F=\frac{I H K_{t}-I H K_{t-1}}{I H K_{t-1}} \times 100$ \\
\hline Kontrol & $\begin{array}{l}\text { Indeks Produksi } \\
\text { Industri } \\
(\Delta \mathrm{IPI})\end{array}$ & $\Delta I P I=\frac{I P I_{t}-I P I_{t-1}}{I P I_{t-1}} \times 100$ \\
\hline
\end{tabular}

\subsection{Metode Analisis Data}

Teknis analisis yang digunakan pada penelitian ini adalah analisis regresi linier berganda (Multiple Linier Regression Analysis) dengan tingkat signifikansi ( $\alpha=5 \%)$. Analisis linier berganda digunkan untuk menjawab hipotesis yang telah diajukan. Metode analisis ini digunakan untuk menjelaskan hubungan antara dua variabel bebas (independent variable) atau lebih terhadap satu variabel terikat (dependent variable).Adapun model persamaan yang digunakan untuk menguji hipotesis adalah sebagai berikut:

$R_{t}=\alpha+\beta_{1} \Delta B I_{t}+\beta_{2} I N F_{t-1}+\beta_{3} \Delta I P I_{t-2}+\varepsilon_{t}$ $\Delta R V_{t}=\alpha+\beta_{1} \Delta B I_{t}+\beta_{2} I N F_{t-1}+\beta_{3} \Delta I P I_{t-2}+\varepsilon_{t}$ 
Keterangan:

$R_{\mathrm{t}} \quad=$ Tingkat pengembalian pasar pada periode $\dagger$

$\Delta R V_{\mathrm{r}}=$ Realized Volatility pada periode $\dagger$

$\alpha \quad=$ Intercept persamaan regresi

$\beta_{\sharp} \quad=$ Koefisien regresi

$\Delta B I_{\mathrm{t}}=$ Bl rate pada periode $\dagger$

$I N F_{\mathrm{t}-1}=$ Inflasi pada periode $\mathrm{t}-1$

$I P I_{\mathrm{t}-2}=$ Indeks Produksi Industri pada periode $\mathrm{t}-2$

$\varepsilon \quad=$ koefisien eror

$\dagger \quad=$ periode sampel

\section{Hasil dan Pembahasan}

\subsection{Hasil Analisis Penelitian}

Berdasarkan data dari variabel-variabel yang telah diukur dan sudah dilakukan uji asumsi klasik, maka perlu dilakukan analisis untuk mengetahui pengaruh variabel independen terhadap dependen. Hasil uji regresi yang menguji pengaruh variabel independen, yaitu BI rate dengan variabel kontrol inflasi dan indeks produksi industri terhadap market return dan volatilitas indeks LQ45 adalah sebagai berikut:

Tabel 4.1

Hasil Analisis Regresi Berganda

\begin{tabular}{|c|c|c|c|c|}
\hline \multirow{2}{*}{ Variabel } & \multicolumn{2}{|c|}{ Market Return } & \multicolumn{2}{c|}{ Volatilitas Return } \\
\cline { 2 - 5 } & $\begin{array}{c}\text { Unstandardized } \\
\text { Koefisien Regresi }\end{array}$ & Sig. t & $\begin{array}{c}\text { Unstandardized } \\
\text { Koefisien Regresi }\end{array}$ & Sig. $\mathbf{t}$ \\
\hline Konstanta & 0.374 & 0.555 & -0.012 & 0.446 \\
\hline$\Delta$ BI rate & 1.521 & 0.238 & 0.072 & $0.030^{*}$ \\
\hline Inflasi & -0.029 & 0.786 & 0.004 & 0.204 \\
\hline$\Delta$ IPI & -0.060 & 0.167 & 0.000099 & 0.927 \\
\hline $\mathrm{R}^{2}$ & 0.056 & & 0.153 & \\
\hline F-Statistic & 0.385 & & 0.034 \\
\hline
\end{tabular}

Berdasarkan Tabel 4.2 menunjukkan variabel $\Delta \mathrm{BI}$ rate berpengaruh positif terhadap return indeks LQ45 sedangkan variabel kontrol inflasi dan $\Delta I P I$ berpengaruh negatif terhadap return indeks LQ45. Namun uji signifikasi † menunjukkan variabel $\Delta \mathrm{BI}$ rate, inflasi dan $\Delta \mathrm{IPI}$ tidak signifikan terhadap return indeks LQ45 (signifikansi † lebih besar dari 0.05). Berdasarkan hasil analisis regresi dengan variabel volatilitas return menunjukkan bahwa $\Delta \mathrm{BI}$ rate, inflasi dan $\Delta \mathrm{IPI}$ berpengaruh positif terhadap volatilitas return. Hasil uji signifikansi † menunjukkan bahwa hanya variabel $\Delta \mathrm{B}$ I rate yang berpengaruh signifikan terhadap volatilitas return (nilai signifikansi $\dagger$ lebih 


\section{Alan Fatih \\ Fitri Ismiyanti}

kecil dari 0,05$)$, sedangkan variabel kontrol inflasi dan $\Delta \mathrm{PPI}$ tidak signifikan terhadap volatilitas return (signifikansi t lebih besar dari 0,05).

Uji F digunakan untuk melihat pengaruh secara bersama-sama variabel independen terhadap variabel dependen. Dari tabel 4.2 nilai F statistik model 1 sebesar 0.385 sehingga HO diterima yang berarti semua variabel independen dan variabel kontrol secara simultan tidak berpengaruh signifikan terhadap market return indeks LQ45. Sedangkan nilai $F$ statistik pada model 2 sebesar 0.034 sehingga HO ditolak yang berarti semua variabel independen dan variabel kontrol secara simultan berpengaruh signifikan volatilitas indeks LQ45.

Koefisien determinasi R2 pada model 1 sebesar 0.056 yang berarti hanya 5.6 persen variabilitas return indeks LQ45 dapat dijelaskan oleh variabel $\Delta \mathrm{BI}$ rate, inflasi dan $\Delta \mathrm{IPI}$, sisanya sebesar 94.4 persen dijelaskan oleh variabel lain yang tidak digunakan dalam penelitian. Sedangkan koefisien determinasi R2 pada model 2 sebesar 0.153 yang berarti hanya 15.3 persen variabilitas volatilitas return indeks LQ45 dapat dijelaskan oleh variabel $\Delta B \mid$ rate, inflasi dan $\Delta \mathrm{IPI}$, sisanya sebesar 84.7 persen dijelaskan oleh variabel lain yang tidak digunakan dalam penelitian.

\subsection{Pembahasan}

\subsubsection{Pengaruh Perubahan BI Rate terhadap Market Return Indeks LQ45}

Perubahan $\mathrm{Bl}$ rate berpengaruh positif tidak signifikan terhadap market return indeks LQ45. Hasil ini bertolak belakang dengan hipotesis penelitian yang menyatakan bahwa pengaruh BI rate berpengaruh negatif terhadap market return indeks LQ45. Pengaruh $\Delta \mathrm{BI}$ rate terhadap market return tidak signifikan diduga karena pergerakan LQ45 lebih di pengaruhi oleh pergerakan indeks bursa regional dan perilaku investor. Hasil ini serupa dengan penelitian Prastowo (2007) yang menyatakan bahwa pasar modal yang diwakili oleh IHSG sama sekali tidak merespon perubahan BI rate dan cenderung di pengaruhi oleh pergerakan indeks bursa regional yang di proksikan dengan Straits Times Index (STI).

Tidak signifikannya pengaruh perubahan Bl rate terhadap market return juga dapat disebabkan oleh ketidakpercayaan investor terhadap bank sentral di negara berkembang sehingga terjadi respons yang beragam dari investor karena dampak dari pengumuman kebijakan moneter ini. Hasil ini konsisten dengan penelitian oleh Vithessonthi dan Techarongrojwong (2013) yang menyatakan bahwa tidak adanya dampak perubahan bunga bank sentral Thailand pada abnormal return karena ketidakpercayaan investor terhadap keputusan Bank of Thailand. Frankel (2011) juga mengemukakan bahwa bank sentral di negara berkembang mempunyai kredibilitas yang rendah.

\subsubsection{Pengaruh Perubahan BI Rate terhadap Volatilitas Indeks LQ45}




\section{Jurnal Manajemen Teori dan Terapan Tahun 8. No. 1, April 2015}

Berdasarkan hasil regresi, dapat diketahui bahwa perubahan BI rate berpengaruh positif signifikan terhadap volatilitas. Pengaruh positif ini berarti kenaikan Bl rate akan meningkatkan volatilitas yang terjadi di indeks LQ45. Pasar akan semakin bergejolak seiring dengan pengumuman kenaikan BI rate oleh gubernur Bl karena investor akan menganggap bahwa kenaikan bunga BI rate adalah sinyal negatif perekonomian di Indonesia.

Peningkatan bunga Bl rate ini menunjukkan bahwa pemerintah menerapkan kebijakan yang ketat untuk menekan laju inflasi dengan mengontrol jumlah uang beredar sehingga perekonomian akan cenderung menurun. Hal inilah yang menjadikan volatilitas semakin tinggi karena ketidakpastian kondisi ekonomi ke depan serta imbal hasil yang tidak pasti pula. Bekaert dan Harvey (1995) menjelaskan bahwa volatilitas di negara berkembang (emerging market) cenderung lebih tinggi dibanding negara maju. Volatilitas yang tinggi ini dilatarbelakangi oleh ketidakstabilan ekonomi.

\subsubsection{Pengaruh Variabel Kontrol terhadap Market Return dan Volatilitas}

Inflasi yang digunakan sebagai kontrol atas pengaruh variabel makroekonomi terlihat tidak signifikan baik terhadap market return maupun volatilitas. Hasil ini tidak sesuai dengan hipotesis yang menyatakan bahwa inflasi berpengaruh negatif terhadap market return dan berpengaruh positif terhadap volatilitas. Hasil ini kemungkinan di sebabkan karena investor dalam pasar modal kurang memperhatikan besarnya inflasi karena inflasi di negara berkembang dianggap akan tetap tinggi. Frankel (2011) menjelaskan bahwa program stabilisasi inflasi di negara berkembang sering terjadi kegagalan dan inflasi di negara berkembang tetap tinggi sehingga investor asing tidak terlalu memperhatikan adanya inflasi. Reilly dan Brown (2012:358) pun menjelaskan bahwa pengaruh inflasi terhadap harga saham tidak secara langsung dan tidak konsisten tergantung pada besaran inflasi dan return perusahaan.

Indeks produksi industri yang juga sebagai variabel kontrol juga menunjukkan hasil yang tidak signifikan terhadap market return dan volatilitas. Hasil ini berbeda dengan hipotesis yang menyatakan bahwa indeks produksi industri berpengaruh positif terhadap market return dan berpengaruh negatif terhadap volatilitas. Tidak signifikannya indeks produksi industri ini disebabkan karena keterbatasan data yang di dapat oleh BPS. Pengumpulan data output dari industri yang cukup lama membuat indeks ini mempunyai lag 2 bulan sehingga investor cenderung mengabaikan data indeks produksi industri ini untuk acuan kondisi perekonomian di Indonesia.

Komposisi indeks produksi industri pun terdiri dari perusahaan besar dan sedang dimana sebagian besar perusahaan tersebut tidak listing di bursa efek. Penelitian Abugri (2006) di 


\section{Alan Fatih \\ Fitri Ismiyanti}

Mexico menyatakan bahwa hanya nilai tukar yang mempunyai hubungan signifikan, sedangkan suku bunga, produksi industri dan jumlah uang beredar terlihat tidak signifikan.

\section{Kesimpulan}

Berdasarkan hasil penelitian dan hasil analisis yang telah dijabarkan sebelumnya, maka kesimpulan yang dapat diambil dari penelitian ini :

1. Perubahan BI rate berpengaruh positif tidak signifikan terhadap market return indeks LQ45.

2. Perubahan BI rate berpengaruh positif signifikan terhadap volatilitas indeks LQ45.

\section{Daftar Referensi}

Alexander, Carol. 2001. Market Models A Guide to Financial Data Analysis. England: John Wiley \& Sons, Inc.

Bekaert, G \& Campbell R. Harvey. 1995. Emerging Equity Market Volatility. NBER Working Paper No. 5307.

Chuliá, Helena, et al. 2009. Asymmetric effects of federal funds target rate changes on S\&P100 stock returns, volatilities and correlations. Journal of Banking \& Finance 34 834-839.

Fama, Eugene F. 1970. Efficient Capital Markets: A Review of Theory and Empirical Work. The Journal of Finance, Vol. 25, No. 2 pp. 383-417.

Fatih, Alan \& Fitri Ismiyanti. 2015. Pengaruh Perubahan Bl Rate terhadap Market Return dan Volatilitas Indeks LQ45, Departemen Manajemen Universitas Airlangga. 83

Frankel, Jaffrey. 201 1. Monetary Policy in Emerging Markets. Handbook of Monetary Economics. Vol 3.

Gitman, Lawrence J., and Michael D. Joehnk. 2005. Fundamental of Investing. Ninth Edition. New Jersey: Pearson Education.

Gospodinov, Nikolay \& Ibrahim Jamali. 2012. The effects of Federal funds rate surprises on S\&P 500 volatility and volatility risk premium. Journal of Empirical Finance 19 497-510.

Latumaerissa, Julius R. 201 1. Bank dan Lembaga Keuangan Lain. Jakarta: Salemba Empat.

Mishkin, Frederic S. 2007. Monetary Policy Strategy. Cambridge: MIT Press.

Prastowo, Joko Nugroho. 2007. Dampak Bl Rate terhadap Pasar Keuangan : Mengukur Signifikansi Respon Instrumen Pasar Kevangan Terhadap Kebijakan Moneter. Working Paper BI. WP/21/2007. 


\section{Jurnal Manajemen Teori dan Terapan Tahun 8. No. 1, April 2015}

Reilly, Frank K \& Keith C. Brown. 2012. Analysis of Investment \& Management Portofolios. 10th ed. Boston: Cengage Learning.

Republik Indonesia. 1995. Undang-undang No. 8 tahun 1995 tentang Pasar Modal.

Thorbecke, Willem \& Tarik Alami. 1994. The Effect of Changes in the Federal Funds Rate Target on Stock Price in the 1970s. Journal of Economics and Business 46:13-19.

Vithessonthi, Chaiporn \& Yaowaluk Techarongrojwong. 2013. Do monetary policy announcements affect stockprices in emerging market countries? The case of Thailand. J. of Multi. Fin. Manag. 23 (2013) 446-469 